\title{
PERSEPSI MAHASISWA TENTANG KEGIATAN LDK (LATIHAN DASAR KEPEMIMPINAN) DALAM MENINGKATAN KETRAMPILAN KOMUNIKASI ANTAR-PRIBADI
}

\author{
Mutmainatul Mardiyah \\ Universitas Mochammad Husni Thamrin \\ mimifatchan95@gmail.com
}

\begin{abstract}
Abstrak
Pada tingkat pendidikan tinggi, proses pendidikan yang diterapkan kepada siswa adalah proses pembelajaran dari implementasi humaniora. Sejalan dengan standar pendidikan tinggi nasional, fakultas Teknik Industri Universitas Trisakti memiliki misi, yang salah satu misinya adalah mempersiapkan lulusan yang berpengetahuan luas, berbudi luhur sesuai dengan Trikrama dan Teknologi berbasis kewirausahaan. Dalam upaya menerapkan nilai kemanusiaan dan untuk mewujudkan misi di atas, siswa semester pertama selalu diprogram untuk mengikuti pelatihan kepemimpinan dasar atau LDK. Penelitian ini adalah untuk menggambarkan bagaimana persepsi siswa tentang LDK (Pelatihan Dasar Kepemimpinan) meningkatkan keterampilan komunikasi interpersonal siswa. Penelitian ini dilakukan di Fakultas Teknologi Industri, Universitas Trisakti. Hasil penelitian adalah sebagai berikut: (1) Persepsi mahasiswa teknik industri tentang LDK pada umumnya baik. Pencapaian semua indikator persepsi siswa tentang LDK mencapai 82,77\% atau merupakan pencapaian yang sangat tinggi. (2) Program LDK yang dilaksanakan di Fakultas Teknologi Industri, Universitas Trisakti umumnya baik. Pencapaian semua indikator keterampilan komunikasi interpersonal siswa mencapai $81,66 \%$ atau itu pencapaian yang sangat tinggi. (3) Persepsi siswa tentang LDK telah berhasil diakui untuk meningkatkan keterampilan komunikasi interpersonal siswa di Fakultas Teknologi Industri, Universitas Trisakti. Berdasarkan hasil penelitian, keterampilan komunikasi interpersonal siswa dapat ditingkatkan dengan meningkatkan indikator persepsi siswa tentang LDK melalui program LDK. Ini membuktikan bahwa persepsi siswa tentang LDK dapat meningkatkan keterampilan komunikasi interpersonal siswa
\end{abstract}

KEYWORDS, students' perception, leadership basic training (LDK), interpersonal communication skills, industrial engineering students

\section{Latar Belakang}

Standar Nasional Pendidikan Tinggi bertujuan untuk menjamin tercapainya tujuan pendidikan tinggi yang berperan strategis dalam mencerdaskan kehidupan bangsa, memajukan ilmu pengetahuan dan teknologi dengan menerapkan nilai humaniora serta pembudayaan dan pemberdayaan bangsa Indonesia yang berkelanjutan. Pada tingkat perguruan tinggi, proses pendidikan yang diterapkan pada mahasiswa adalah proses belajar tentang penerapan nilai humaniora. Sejalan dengan standar nasional pendidikan tinggi, Fakultas Teknik Industri Universitas Trisakti memiliki misi, yang salah satu misinya adalah menyiapkan lulusan yang berpengetahuan, berbudi luhur sesuai dengan trikrama dan berjiwa wirausaha berbasis teknologi.

Latar belakang penelitian ini dilakasanakan karena terkait dengan misi dan visi yang disampaikan diatas. Dalam usaha penerapan nilai humaniora dan untuk mewujudkan misi tersebut di atas, mahasiswa teknik industri universitas Trisakti semester pertama selalu 
diprogramkan untuk mengikuti latihan dasar kepemimpinan atau LDK. LDK merupakan sebuah pelatihan dasar tentang segala hal yang berkaitan dengan kepemimpinan, yang bertujuan untuk memberikan bekal kepemimpinan. Oleh karenanya dibutuhkan persepsi yang baik oleh mahasiswa tentang LDK.

Persepsi sebagai proses dimana individu mengatur dan mengintrepetasikan kesan-kesan sensoris mereka guna memberikan arti bagi lingkungan mereka. (Robins, 2008: 175). Persepsi juga diartikan sebagai suatu proses yang kompleks dimana kita menerima dan menyadap informasi dari lingkungan. Persepsi juga merupakan proses psikologis sebagai hasil penginderaan serta proses terakhir dari kesadaran, sehingga membentuk proses berpikir. Persepsi seseorang akan mempengaruhi proses belajar (minat) dan mendorong mahasiswa untuk melaksanakan sesuatu (motivasi) belajar. Oleh karena itu, menurut Semiun (2006: 279), persepsi merupakan kesan yang pertama untuk mencapai suatu keberhasilan. Dengan memiliki persepsi yang baik tentang LDK, yang mana bahwa program LDK sangat memberi manfaat bagi mahasiswa, maka penelitian ini dilaksanakan untuk menggambarkan bagaimana keterampilan komunikasi antar pribadi mahasiswa bisa menjadi lebih baik.

Dalam berkomunikasi, khususnya berkomunikasi antar pribadi, kita memerlukan beberapa teori sebagai hakikat kita dalam berkomunikasi agar terjadi berlangsungnya komunikasi yang tertata dengan benar. Teori social exchange merupakan salah satu teori dalam bidang komunikasi yang biasanya disebut sebagai pertukaran sosial. Monge dan Contractor (2003) mengemukakan bahwa orang menghitung nilai keseluruhan dari sebuah hubungan dengan mengurangkan pengorbanannya dari penghargaan yang diterima. Teori ini dikembangkan oleh ahli psikolog John Thibaut dan Harlod Kelley (1959), dan beberapa orang sosiolog yang bernama George Homans (1961), Richard Emerson (1962), dan Peter Blau (1964). Social exchange memiliki hubungan dengan pertukaran orang lain yang dapat menghasilkan sesuatu. Komunikasi bisa terjadi ketika adanya lingkungan dan sikap individu yang saling berhubungan. Di lingkungan masyarakat, pastinya kita akan menemui berbagai orang dengan sikap yang berbeda-beda yang saling terkait dan berhubungan.

Melalui program LDK, mahasiswa jurusan teknik industri diharapkan memiliki persepsi yang baik tentang LDK, bahwa program LDK sangat memberi manfaat bagi mahasiswa untuk menjadikan lulusan yang memiliki jiwa kepemimpinan dan berketerampilan komunikasi antar pribadi yang lebih baik. Oleh karenanya, semakin tinggi persepsi mahasiswa tentang LDK, maka semakin baik ketrampilan komunikasi antar pribadi yang dimiliki mahasiswa. Sehingga bisa disimpulkan bahwa tujuan penelitian ini adalah untuk mengetahui bagaimana persepsi tentang LDK bisa meningkatkan ketrampilan komunikasi antar pribadi mahasiswa, dimana ini terkait dan sejalan dengan salah satu visi dan misi dari jurusan teknik industri di Universitas Trisakti, yaitu menyiapkan lulusan yang berpengetahuan, berbudi luhur sesuai dengan trikrama dan berjiwa wirausaha berbasis teknologi. Sehingga hasil penelitian ini juga bisa memberikan pertimbangan bagi fakultas-fakultas lain untuk memberikan kegiatan LDK kepada mahasiswa baru sebagai bekal mereka dalam bermasyarakat dengan berjiwa kepemimpinan dan berketrampilan berkomunikasi antar pribadi yang baik.

\section{Metode Penelitian}

Sesuai dengan permasalahan yang diteliti dan tujuan penelitian yang ingin dicapai, penelitian ini menggunakan metode penelitian deskriptif kuantitatif. Penggunaan metode deskritif dalam penelitian ini dimaksudkan untuk mengetahui secara holistik dan mendalam tentang permasalahan yang akan diteliti di lapangan khususnya mengenai persepsi mahasiswa tentang LDK dalam rangka meningkatkan ketrampilan komunikasi antar pribadi mahasiswa. Metode deskriptif ini mendeskripsikan hasl-hasil pengukuran variabel dari variabel persepsi mahasiswa tentang LDK dan variable ketrampilan komunikasi antar pribadi. Selanjutnya, penelitian ini diawali dengan proses pengumpulan data, pengolahan data, pendeskripsian, dan 
pembahasan hasil temuan yang didukung oleh teori sebagai acuan dalam menginterpretasikan hasil penelitian. Unit analisis ini merupakan informasi atau sumber data yang akan digali oleh peneliti untuk mendapatkan informasi dan data tentang masalah penelitian yang akan melibatkan mahasiswa jurusan Teknik Industri di Universitas Trisakti, Jakarta.

Instrumen penelitian merupakan suatu alat untuk mengukur gejala sosial yang diamati. Untuk tidak menimbulkan kekeliruan pengertian, maka disusun instrumen melalui beberapa langkah sebagai persyaratan penyusunan instrumen, antara lain: (1) melakukan pengkajian terhadap semua teori yang berhubungan dengan variable-variable yang diteliti, (2) mengkaji masing-masing variable tersebut diberi arti melalui definisi konseptual dan definisi operasional yang selanjutnya menentukan indikator dan subindikator, (3) menyusun kisi-kisi, (4) menyusun butir pernyataan dan menetapkan skala pengukuran, (5) melaksanakan ujicoba instrumen, (6) pengujian terhadap masing-masing pernyataan dengan pengujian validitas dan realibilitas instrumen penelitian.

Dalam suatu konsepsi bahwa instrumen yang digunakan dalam menjaring data adalah dalam bentuk angket berupa kuesioner dan disusun menurut metode skala Likert dan dirumuskan dalam bentuk kontinum dengan skala 5 (lima). Untuk variable persepsi mahasiswa tentang LDK menggunakan skala nilai: Selalu, Sering, Kadang-Kadang, Jarang, Tidak Pernah. Sementara itu, untuk variable ketrampilan komunikasi antar pribadi, menggunakan skala penilaian: Sangat Setuju, Setuju, Kurang Setuju, Tidak Setuju, dan Sangat Tidak Setuju. Penetapan terhadap skala penilaian persepsi mahasiswa tentang LDK, maka jawaban yang terdapat pada masing-masing jawaban pernyataan adalah: Selalu=5, Sering=4, KadangKadang=3, Jarang $=2$, Tidak Pernah $=1$. Sedangkan untuk skala penilaian ketrampilan komunikasi antar pribadi menggunakan skala dalam bentuk: Sangat Setuju=5, Setuju=4, Tidak Setuju=3, Kurang Setuju=2, dan Sangat Tidak Setuju=1

\section{Hasil \& Pembahasan}

Deskripsi data hasil temuan disajikan dengan maksud memberikan gambaran umum mengenai penjelasan dari data yang dicari dan diperoleh melalui angket atau kuesioner dan wawancara, yang kemudian disesuaikan dengan teori dari variable terkait. Penelitian ini membahas dua variable yaitu persepsi mahasiswa tentang LDK dan ketrampilan komunikasi antar pribadi mahasiswa di jurusan Teknik Industri, Universitas Trisakti, Jakarta. Berikut ini adalah deskripsi data dari masing-masing variabel:

Data Persepsi Mahasiswa tentang LDK di jurusan Teknik Industri, Universitas Trisakti Jakarta.

Persepsi merupakan pengalaman tentang objek, peristiwa, hubungan-hubungan yang diperoleh dengan menyimpulkan informasi dan menafsirkan pesan. Disamping faktor-faktor luar yang mempengaruhi persepsi, ada faktor-faktor internal personal umum misalnya faktorfaktor biologis, sosiopsikologis, faktor fungsional, yakni latar belakang kebutuhan, pengalaman masa lalu orang yang memberi respons terhadap stimuli. Dari pengumpulan data pada angket yang disebar, diperoleh jawaban responden terhadap instrumen yang mengukur faktor dalam situasi yaitu: Waktu, Keadaan/Tempat, dan Keadaan Sosial. Juga diperoleh jawaban responden terhadap instrument yang mengukur faktor pada pemersepsi, yaitu sikap, motif, kepentingan, pengalaman, pengharapan.

Data Ketrampilan Komunikasi Antar-pribadi Mahasiswa di jurusan Teknik Industri, Universitas Trisakti, Jakarta.

Menurut teori penetrasi sosial, prinsip utama bagi komunikasi pada pertemuan pertama adalah norma resiprositas. Norma ini menilai bahwa individu memiliki kewajiban untuk mengembalikan pengungkapan pihak lain yang diterima. Kemudian, menurut teori ini juga, Secara langsung akan mengenali diri orang lain dengan cara "masuk ke dalam" (penetrating) diri orang yang bersangkutan. Hal ini bertujuan untuk mengetahui beberapa informasi terkait 
diri orang lain. Altman dan Taylor mengajukan empat tahap perkembangan hubungan antar individu, meliputi tahap orientasi, yaitu komunikasi yang terjadi pada tahap ini bersifat tidak pribadi. Keduanya sudah merasa cukup mendapat pesan balik; lalu tahap pertukaran efek eksploratif, yaitu tahap munculnya keterbukaan yang lebih dalam karena telah timbul rasa percaya dan merasa cocok satu sama lain. Selanjutnya adalah tahap pertukaran efek, yaitu perasaan kritis dan evaluatif mulai muncul pada tingkat yang lebih tinggi dan dalam. Tahap terakhir adalah tahap pertukaran stabil, yaitu adanya keintiman, masing-masing individu merasa memiliki komunikasi yang efektif dengan sangat baik satu sama lain.

Dalam hal ini dilakukan penyebaran angket kepada 28 mahasiswa sebagai responden. Dari pengumpulan data pada angket tersebut diperoleh jawaban responden terhadap instrumen yang mengukur faktor-faktor ketrampilan komunikasi antar pribadi mahasiswa, yaitu berupa tahapan-tahapan yang meliputi: tahap orientasi, tahap pertukaran efek eksploratif, tahap pertukaran efek, dan tahap tahap pertukaran stabil,

Data Persepsi Mahasiswa tentang LDK dan Ketrampilan Komunikasi Antar-pribadi Mahasiswa di jurusan Teknik Industri, Universitas Trisakti, Jakarta.

Persepsi mahasiswa tentang LDK dalam meningkatkan ketrampilan komunikasi antar pribadi mahasiswa merupakan penilaian yang menekankan pada penilaian mahasiswa tentang LDK yang dipengaruhi beberapa faktor. Persepsi merupakan pengalaman tentang objek, peristiwa, hubungan-hubungan yang diperoleh dengan menyimpulkan informasi dan menafsirkan pesan. Disamping faktor-faktor luar yang mempengaruhi persepsi, ada faktor-faktor internal personal umum misalnya faktor-faktor biologis, sosiopsikologis, faktor fungsional, yakni latar belakang kebutuhan, pengalaman masa lalu orang yang memberi respons terhadap stimuli.

Dari pengumpulan data pada angket yang disebar, diperoleh jawaban responden terhadap instrumen yang mengukur faktor dalam situasi yaitu: Waktu, Keadaan/Tempat, dan Keadaan Sosial. Juga diperoleh jawaban responden terhadap instrument yang mengukur faktor pada pemersepsi, yaitu sikap, motif, kepentingan, pengalaman, pengharapan. Instrumen lainnya adalah mengukur faktor pada target, yaitu: hal baru, gerakan, bunyi, ukuran, latar belakang, kedekatan.

Melalui faktor-faktor yang mempengaruhi persepsi mahasiswa dan ciri-cirinya yang telah dijelaskan pada data persepsi mahasiswa tentang LDK, maka ketrampilan komunikasi antar pribadi mahasiswa bisa tercapai. Ketrampilan komunikasi antar pribadi mahasiswa menjadi menjadi salah satu yang harus diperhatikan karena ini merupakan sebagian tujuan yang ingin dicapai dari langkah-langkah yang dilakukan dalam persepsi mahasiswa tentang LDK. Dengan gambaran tersebut diatas maka bisa diutarakan bahwa persepsi mahasiswa tentang LDK bisa meningkatkan ketrampilan komunikasi antar-pribadi mahasiswa.

\section{Temuan Penelitian Variable Persepsi}

Data tentang variable persepsi mahasiswa tentang LDK diperoleh berdasarkan hasil isian angket pada responden yang terdiri dari 28 (duapuluh delapan) mahasiswa di jurusan teknik industri, Universitas Trisakti, Jakarta, yang terdiri dari 39 butir pernyataan dengan 5 (lima) alternatif jawaban. Setiap butir pernyataan diberi skor 1-5. Dengan demikian, secara teoritis rentang skor berkisar 39-195.

Skor empiris variabel persepsi bervariasi antara 137-195 dengan rentang skor sebesar 58 . Berdasarkan hasil perhitungan statistik deskriptif diperoleh skor rata-rata 161,4; simpangan baku 15,47 ; varians 239,43; modus 173; dan median 161,5.Sebaran skor dari masing-masing responden dapat ditunjukkan pada tabel distribusi frekuensi yang disusun dengan jumlah kelas enam (6) dan panjang kelas sepuluh (10), sebagaimana ditunjukkan pada tabel berikut. 
Tabel 4.1

Distribusi Frekuensi Variabel Persepsi

\begin{tabular}{|c|c|c|c|c|}
\hline No. Kelas & Kelas Interval & \multicolumn{3}{|c|}{ Frekuensi } \\
\hline & & Absolut & Kumulatif & Relatif (\%) \\
\hline 1 & $130-140$ & 3 & 3 & 11 \\
\hline 2 & $141-151$ & 5 & 8 & 18 \\
\hline 3 & $152-162$ & 6 & 14 & 21 \\
\hline 4 & $163-173$ & 8 & 22 & 29 \\
\hline 5 & $174-184$ & 4 & 26 & 14 \\
\hline 6 & $185-195$ & 2 & 28 & 7 \\
\hline JUMLAH & & 28 & & \\
\hline
\end{tabular}

Berdasar tabel di atas, 8 responden atau 29\% menilai persepsi mahasiswa tentng LDK di jurusan teknik industri, Universitas Trisakti Jakarta dibawah rata-rata, 6 responden atau 21\% berada pada skor rata-rata, dan 14 responden atau 50\%) berada di atas rata-rata. Berdasar penyebaran skor variabel persepsi mahasiswa, dapat dikemukakan bahwa secara umum persepsi mahasiswa tentang LDK di jurusan teknik Industri, universitas Trisakti adalah di atas rata-rata.

\section{Temuan Penelitian Variabel Ketrampilan Komunikasi Antar-Pribadi}

Data tentang variable ketrampilan komunikasi antar-pribadi diperoleh berdasarkan hasil isian angket pada responden yang terdiri dari 28 (duapuluh delatan) mahasiswa di jurusan teknik industri, universitas Trisakti Jakarta, yang terdiri dari 31 butir pernyataan dengan 5 (lima) alternatif jawaban. Setiap butir pernyataan diberi skor 1-5. Dengan demikian, secara teoritis rentang skor berkisar 31-155. Skor empiris variabel ketrampilan komunikasi antar-pribadi bervariasi antara 114-148 dengan rentang skor sebesar 34. Berdasarkan hasil perhitungan statistik deskriptif diperoleh skor rata-rata 127,03; simpangan baku 8,44; varians 71,36; modus 123; dan median 126.

Sebaran skor dari masing-masing responden dapat ditunjukkan pada tabel distribusi frekuensi yang disusun dengan jumlah kelas 6 dan panjang kelas 5, sebagaimana ditunjukkan pada tabel berikut.

Tabel 4.6

Distribusi Frekuensi Variabel Ketrampilan Komunikasi Antar-Pribadi

\begin{tabular}{|c|c|c|c|c|}
\hline No. Kelas & Kelas Interval & & Frekuensi & \\
\hline & & Absolut & Kumulatif & Relatif (\%) \\
\hline 1 & $113-118$ & 6 & 6 & 21 \\
\hline 2 & $119-124$ & 7 & 13 & 25 \\
\hline 3 & $125-130$ & 7 & 20 & 25 \\
\hline 4 & $131-136$ & 3 & 23 & 11 \\
\hline 5 & $137-142$ & 4 & 27 & 14 \\
\hline 6 & $143-148$ & 1 & 28 & 4 \\
\hline JUMLAH & & 28 & & \\
\hline
\end{tabular}

Berdasar tabel di atas, 13 responden (46\%) dinilai ketrampilan komunikasi antar-pribadi mahasiswa di juruasan teknik indusri universitas Trisakti di atas rata-rata, 7 responden atau $25 \%$ berada pada skor rata-rata, dan 8 responden atau $29 \%$ berada di bawah rata-rata. Berdasar penyebaran skor variabel ketrampilan komunikasi, dapat dikemukakan bahwa secara umum ketrampilan komunikasi antar-pribadi mahasiswa di jurusan teknik Indusri universitas Trisakti adalah di atas rata-rata. 


\section{Kesimpulan Dan Saran}

Dari hasil analisis yang dibahas pada bab sebelumnya, maka dapat ditarik kesimpulan sebagai berikut: 1) Persepsi mahasiswa tentang LDK dalam meningkatkan ketrampilan komunikasi antar pribadi mahasiswa di jurusan teknik industri Universitas Trisakti dipengaruhi beberapa faktor, yaitu tentang kegiatan-kegiatan LDK yang mencakup kegiatan di dalam dan di luar ruangan. 2)Persepsi mahasiswa tentang LDK di jurusan teknik Industri universitas Trisakati Jakarta merupakan penilaian pengalaman tentang objek, peristiwa, hubungan-hubungan yang diperoleh dengan menyimpulkan informasi dan menafsirkan pesan, sehingga kegiatan ini mempengaruhi persepsi mereka. Melalui kegiatan LDK, mahasiswa menilai sangat baik, dan penilaian ini dipengaruhi oleh faktor-faktor internal personal umum yaitu faktor-faktor biologis, sosiopsikologis, faktor fungsional, yakni latar belakang kebutuhan, pengalaman masa lalu orang yang memberi respons terhadap stimuli. 3). Ketrampilan komunikasi antarpribadi mahasiswa di jurusan teknik industri Universitas Trisakti telah meningkat dengan sangat baik melalui persepsi mahasiswa setelah mengikuti kegiatan-kegiatan LDK. 4). Dengan gambaran tersebut diatas maka bisa diutarakan bahwa ketrampilan komunikasi antarpribadi mahasiswa bisa ditingkatkan dengan persepsi mahasiswa melalui kegiatan-kegiatan LDK di jurusan teknik industri Universitas Trisakti.

Berdasarkan kesimpulan diatas, maka penulis memberikan beberapa saran sebagai berikut: 1). Ketrampilan komunikasi antar-pribadi mahasiswa bisa ditingkatkan dengan adanya persepsi yang baik tentang kegiatan-kegiatan LDK. Kondisi ini bisa memperbaiki fungsi kepemimpinan saat mahasiswa sudah terjun di masyarakat. 2). Persepsi mahasiswa tentang LDK bisa menjadi salah satu faktor keberhasilan mereka sebagai seorang pemimpin karena ketrampilan komunikasi antar-pribadi yang baik yang mereka miliki setelah mengikuti kegiatan-kegiatan LDK. 3). Walaupun LDK dilaksanakan dan diprogramkan untuk mahasiwa baru, di sarankan agar mahasiswa tetap untuk melaksanakan nilai-nilai dan pelajaran-pelajaran yang diperoleh selama LDK sepanjang mereka masih menjadi mahasiwa di kampusnya, sehingga ketrampilan berkomunikasi antar-pribadi mahasiswa tetap baik. 


\section{Referensi}

- Ahmad, F. (2009). Students' perception of the teachers' teaching of literature communicating and understanding through the eyes of the audience. European Journal of social sciences, 7(3), 3-15.

- $\quad$ Ajibade, Y. A. \& Ehindero, O. J. (2000). What our students say about how we teach. Ife Journal Education Studies, 7(1), 1-9.

- Cress, C. M., Astin, H. S., Zimmerman-Oster, K., \& Burkhardt, J. C. (2001).Developmental Outcomes of College Students' Involvement in Leadership Activities. Journal of College Student Development, 42(1), 15-27.

- Gallagher, M.L., Marshall, J.C., Pories, M.L., Daugherty, M. (2014). Factors Effecting Undergraduate Leadership Behaviors. Journal of Leadership Education, 13(1), 4656.

Organizational:

Behavior, Structure, Processes, 2012, New York: Mc Graw-Hill. pp. 344-345.

- Foreman, E.A. \& Retallick, M.S. (2013). Using Involvement Theory to Examine Relationship Between Undergraduate Participation in Extracurricular Activities and Leadership Development. Journal of Leadership Education, 12(2), 56-73.

- $\quad$ Foubert, J.D. \& Urbanski, L.A. (2006). Effects of Involvement in Clubs and Organizations on the Psychosocial Development of First-Year and Senior College Students. NASPA Journal, 43(1), 166-182.

- $\quad$ Kim, K. A., Sax, L. J., Lee, J. J., \& Hagedorn, L. S. (2010). Redefining nontraditional students: Exploring the self-perceptions of community college students. Community 67 College Journal of Research and Practice, 34, 402-422.

- $\quad$ Taylor, A., Bailey, A., Cooper, P., Dwyer, C., Kramarae, C. and Lieb, B., 2007. Gender equity in communication skill. Handbook for achieving gender equity through education, p.281. 